\title{
The Synthesis of Methyl Vitamin A
}

\author{
Masanao Matsui, Toshinobu Ishinara* and Takeshi Kitahara \\ Pesticide Synthesis II, Institute of Physical and Chemical Research, Wako-shi, Saitama \\ Received February 7, 1974
}

Synthesis of methyl vitamin A from $\beta$-irone is described.

In a previous paper ${ }^{11}$ we described a novel synthetic procedure of dienones and the synthesis of irone and ionone by this procedure. If $\beta$-irone is used as a starting material, methyl vitamin $A$ will be obtained by the same procedure as vitamin A synthesis, ${ }^{2)}$ and the synthesis of dimethyl $\beta$-carotene can also be achieved. We are much interested in the biological properties of these two compounds as homologues of vitamin $\mathrm{A}$ and $\beta$-carotene.

In this paper we wish to report the synthesis of methyl vitamin A by the route shown in Fig. 1. by crystallization from the reaction mixture could not be achieved in spite of several trials, probably because of the difficulty to remove minor products. So the synthesis was carried out by employing the procedure described by Pommer et al.," which is the shortest way to reach the final product though the stereoselectivity is sacrificed. The grignard reaction of $\beta$-irone (I) with vinyl magnesium chloride afforded an allyl alcohol (II) which was converted to a triphenyl phosphonium salt (III) by treating with triphenyl-phosphine hydrochloride. Without isolation of the salt (III),

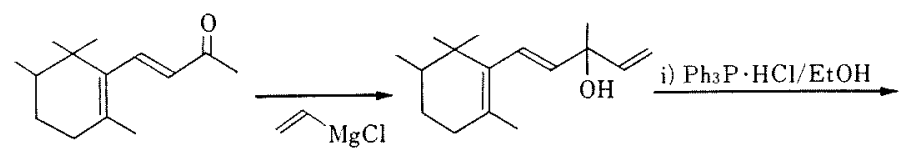

(I)

(II)

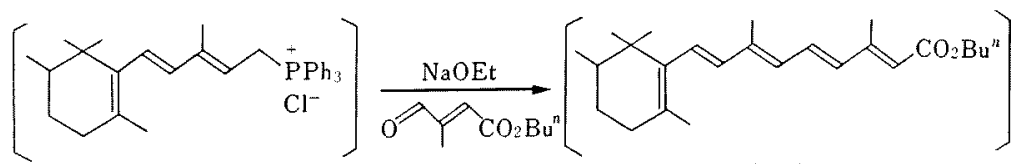

(III)

(IVa)

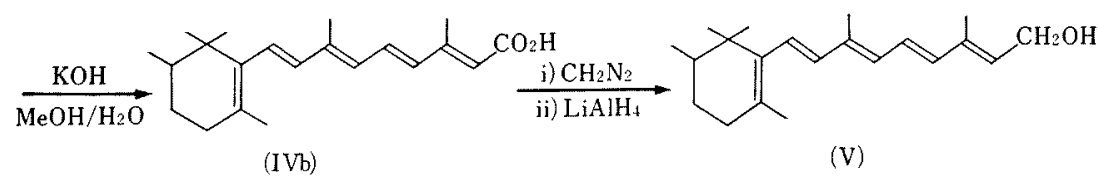

FIG. 1.

The stereoselective method, i.e. Matsui's procedure $^{2 \theta}$ ) seemed to be applicable to this synthesis of methyl vitamin A. However, in this case purification of ironylideneacetic acid

* Research Fellow from Naoetsu Research Laboratory of Shin-etsu Chemical Industry Co., Nakakubiki, Niigata. the Wittig reaction with $n$-butyl $\beta$-formyltrans-crotonate in the presence of sodium ethoxide afforded a crude ester (IVa), which was immediately saponified with methanolic potassium hydroxide to give methyl vitamin A acid. Pure all-trans-methyl vitamin A acid (IVb) was obtained as yellow crystalls in $19 \%$ 
yield from $\beta$-irone by silica gel chromatography, which was then converted to its methyl ester (IVc) with diazomethane. The ester (IVc) was reduced with lithium aluminum hydride in anhydrous ether at $-30^{\circ} \mathrm{C}$ to give methyl vitamin $\mathrm{A}(\mathrm{V})$. The structures of these novel compounds were supported by their physical properties. The physiological activity of methyl vitamin $\mathrm{A}$, i.e., vitamin $\mathrm{A}$ effect on rat etc., is now under investigation and the result will be reported elsewhere.

\section{EXPERIMENTAL}

Mps were uncorrected. The NMR spectra were recorded with spectrometers JNM-XL-60 and Varian HA-100. The IR spectra were taken with spectrometers, Hitachi EPI-G-22 and JASCO IR-A1. The UV spectrum was recorded with a spectrometer Cary-14.

Vinyl ironol (II). To a solution of vinyl magnesium chloride, prepared from $\mathrm{Mg}(0.95 \mathrm{~g}, 0.04 \mathrm{~g}$ atom) and vinyl chloride in THF $(100 \mathrm{ml})$ by the procedure of Suga et al., ${ }^{4 !} \beta$-irone $(3.8 \mathrm{~g}, 0.018 \mathrm{~mole})$ in THF $(10 \mathrm{ml})$ was added dropwise at $40^{\circ} \mathrm{C}$ in a period of $20 \mathrm{~min}$. After the addition was complete, the mixture was stirred for additional $3 \mathrm{hr}$ at room temperature, poured into aqueous $\mathrm{NH}_{4} \mathrm{Cl}$ solution and extracted with ether. The extract was washed with water and dried over $\mathrm{Na}_{2} \mathrm{SO}_{4}$. The solvent was removed in vacuo and the resulting oil was distilled under reduced pressure to give vinyl ironol (II, $3.9 \mathrm{~g}, 90.4 \%$ ). Bp $99 \sim 100^{\circ} \mathrm{C}$ $(0.25 \mathrm{mmHg}), n_{\mathrm{D}}^{26}=1.5057, \mathrm{IR} \nu_{\max }^{\mathrm{film}} \mathrm{cm}^{-1}: 3380(-\mathrm{OH})$, 980 and $920\left(\mathrm{CH}_{2}=\mathrm{CH}-\right)$, NMR $\mathrm{TMS}_{\mathrm{S}}^{\mathrm{CCl}} \mathrm{ppm}: 0.84$ and $1.00(2 \times 3 \mathrm{H}$, each singlet, gem-dimethyl), $0.80 \sim 0.90$ (3H, doublet, $\left.\mathrm{CH}_{3}-\mathrm{CH}^{\prime}-\right), 1.38\left(3 \mathrm{H}\right.$, singlet, $\left.\mathrm{CH}_{3}-\stackrel{\mathrm{C}-}{\mathrm{C}}\right)$, $1.64\left(3 \mathrm{H}\right.$, singlet, $\left.\mathrm{CH}_{3}-\mathrm{C}=\mathrm{C}<\right), 1.00 \sim 2.00(5 \mathrm{H}$, broad, methylene and methine protons), $4.80 \sim 6.20(5 \mathrm{H}$, multiplet, vinyl protons). Anal. Found: C, 81.80; $\mathrm{H}$, 11.20. Calcd. for $\mathrm{C}_{16} \mathrm{H}_{26} \mathrm{O} ; \mathrm{C}, 81.99: \mathrm{H}, 11.18$.

Methyl vitamin $A$ acid ( $I V b)$. A mixture of vinyl ironol (2.3 $\mathrm{g}, 0.01 \mathrm{~mole})$ and triphenylphosphine hydrochloride $(3.5 \mathrm{~g}, 0.012 \mathrm{~mole})$ in absolute ethanol $(25 \mathrm{ml})$ was stirred at $20 \sim 25^{\circ} \mathrm{C}$ under a nitrogen atmosphere for $3 \mathrm{hr}$ to prepare ironylidene-ethyl triphenyl phosphonium chloride. To this stirred solution, sodium exthoxide prepared from $\mathrm{Na}(0.45 \mathrm{~g}, 0.020 \mathrm{~g}$ atom $)$ and absolute ethanol $(5 \mathrm{ml})$, and $n$-butyl $\beta$-formylcrotonate $(1.7 \mathrm{~g}, 0.010$ mole) in ethanol $(10 \mathrm{ml})$ were added dropwise simultaneously at $-30 \sim-40^{\circ} \mathrm{C}$ in a period of $15 \mathrm{~min}$. After the addition was complete, the mixture was stirred at $-10^{\circ} \mathrm{C}$ for $30 \mathrm{~min}$ and at $20^{\circ} \mathrm{C}$ for additional $2 \mathrm{hr}$, poured into dilute $\mathrm{HCl}$ solution and then extracted with hexane. The solvent was removed in vacuo and the residual oil $(4.8 \mathrm{~g})$ was immediately saponified by refluxing with potassium hydroxide $(1 \mathrm{~g})$ in methanol $(16 \mathrm{ml})$ and water $(4 \mathrm{ml})$ for $2 \mathrm{hr}$. Water was added to the reaction mixture and the neutral fraction was removed by extraction with hexane. The aqueous layer was acidified with dilute $\mathrm{HCl}$ solution and extracted with ether repeatedly. The extract was washed with water and dried over $\mathrm{Na}_{2} \mathrm{SO}_{4}$. The solvent was removed in vacuo and the residual oil ( $4.3 \mathrm{~g}$ ) was separated by silica gel chromatography to give a mixture of vitamin A acid $(0.9 \mathrm{~g}$, $29.0 \%$, from which all-trans vitamin A acid was obtained as a yellow crystalline product (600 mg, $19.4 \%$ ) by repeated recrystallization from hexane-ethanol. $\operatorname{mp}_{\mathrm{O}} 144^{\circ} \mathrm{C} \operatorname{IR} \nu_{\max }^{\mathrm{KBr}} \mathrm{cm}^{-1}: 3200 \sim 2300(\stackrel{\mathrm{O}}{\mathrm{C}}-\mathrm{OH}), 1680$

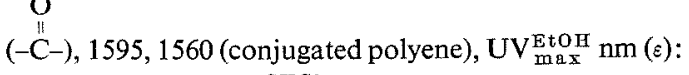
341 (39600). NMR $\delta_{\mathrm{TMS}}^{\mathrm{CHCl}_{3}}$ ppm: 0.88 and $1.03(3 \mathrm{H} \times 2$, singlet, gem-dimethyl), $0.91(3 \mathrm{H}$, doublet, $J=7 \mathrm{~Hz}$, $\left.\mathrm{CH}_{3} \mathrm{CH}\right) 1.30 \sim 1.70(5 \mathrm{H}$, broad, methylene and methine protons), 1.71 ( $3 \mathrm{H}$, singlet, allylic methyl in cyclohexene ring), $2.02\left(3 \mathrm{H}\right.$, singlet, $\mathrm{C}_{7}$-methyl) $2.37(3 \mathrm{H}$, singlet, $\mathrm{C}_{3}$-methyl) $5.77\left(1 \mathrm{H}\right.$, singlet, $\mathrm{C}_{2}$-vinyl proton) $5.40 \sim$ $5.90\left(4 \mathrm{H}\right.$, multiplet, $\left.\mathrm{C}_{4}, \mathrm{C}_{6}, \mathrm{C}_{8}, \mathrm{C}_{9}-\mathrm{H}\right) 6.96(1 \mathrm{H}$, double, doublet, $\left.\mathrm{C}_{4}-\mathrm{H}, J_{\mathrm{C}_{4}-\mathrm{C}_{3}}=15 \mathrm{~Hz}, J_{\mathrm{C}_{4}-\mathrm{C}_{5}}=11 \mathrm{~Hz}\right) 11.6(1 \mathrm{H}$, broad, $-\mathrm{OH}$ ). Anal. Found: C, 79.95; H, 9.39. Calcd. for $\mathrm{C}_{21} \mathrm{H}_{30} \mathrm{O}_{2} ; \mathrm{C}, 80.21 ; \mathrm{H}, 9.62$.

Methyl vitamin $A(V)$. To an ethereal solution $(100 \mathrm{ml})$ of methyl vitamin A acid $(2.1 \mathrm{~g}, 0.007$ mole), diazomethane $(1.0 \mathrm{~g}, 0.024$ mole) in absolute ether $(55 \mathrm{ml})$ was added dropwise at $0^{\circ} \mathrm{C}$. After the addition was complete, the mixture was stirred for additional $1 \mathrm{hr}$ under nitrogen at $0^{\circ} \mathrm{C}$. Unreacted diazomethane was decomposed by excess $50 \%$ acetic acid. The ether solution was washed with aqueous sodium bicarbonate solution and water and dried over $\mathrm{Na}_{2} \mathrm{SO}_{4}$. The solvent was removed in vacuo. To the resulting oil $(2.1 \mathrm{~g})$ in absolute ether $(80 \mathrm{ml}), \mathrm{LiA}_{1} \mathrm{H}_{4}(270 \mathrm{mg}, 0.007$ mole $)$ in ether $(11 \mathrm{ml})$ was added dropwise at $-50^{\circ} \mathrm{C}$. After the reaction mixture was stirred for $2 \mathrm{hr}$ at $-50^{\circ} \mathrm{C}$, methyl acetate was added. The mixture was poured into aqueous $0.5 \mathrm{~N} \mathrm{H}_{2} \mathrm{SO}_{4}$ solution and crushed ice, and extracted with ether. The extract was washed with aqueous sodium bicarbonate solution and water and dried over $\mathrm{Na}_{2} \mathrm{SO}_{4}$. Solvent was removed in vacuo and the resulting oil was separated by silica gel chromatography. All-trans methyl vitamin A was obtained as a yellowish oily product $(570 \mathrm{mg}, 28.3 \%)$. IR $\nu_{\max }^{\mathrm{film}}$ $\mathrm{cm}^{-1}: 3340(-\mathrm{OH}), \mathrm{NMR} \delta_{\mathrm{TMS}}^{\mathrm{CO} \mathrm{MS}^{4}} \mathrm{ppm}: 0.88$ and 1.02 $(2 \times 3 \mathrm{H}$, each singlet, gem-dimethyl), 0.90 (3H, doublet, $\left.J=8 \mathrm{~Hz}, \mathrm{CH}_{3}-\mathrm{CH}-\mathrm{C}-\right), 1.68,1.84$ and $1.95(3 \times 3 \mathrm{H}$, 
each singlet, $\left.\mathrm{CH}_{3}-\stackrel{\mathrm{C}}{\mathrm{C}}=\mathrm{C}<\right), 5.80 \sim 6.60(6 \mathrm{H}$, multiplet, $\mathrm{C}_{2}, \mathrm{C}_{4}, \mathrm{C}_{5}, \mathrm{C}_{6}, \mathrm{C}_{8}, \mathrm{C}_{9},-\mathrm{H}$ ).

\section{REFERENCES}

1) T. Ishihara, T. Kitahara and M. Matsui, $A g r$. Biol. Chem., 38, 439 (1974).

2) a) O. Isler, A. Ronco, W. Guex, N. C. Hindley, W. Huber, K. Dialer and M. Kofler, Helv. Chim. Acta, 32, 489 (1949).

b) W. J. Humphlett and D. A. Van Drop, Rec. Trav. Chim., 68, 604 (1949).

c) W. J. Humphlett and D. M. Burness, U.S.
Patent 2,676,900 (1954) [C.A., 50, 408a (1956)] d) J. Attenburrow, A. F. B. Cameron, J. H. Chapmann, R. M. Evans, B. A. Hems, A. B. A. Jansen and T. Walker, J. Chem. Soc., 1952, 1094.

e) M. Matsui, S. Okano, K. Yamashita, M. Miyano, S. Kitamura, A. Kobayashi, T. Sato and R. Mikami, J. Vitaminol., 4, 178 (1958).

3) H. Pommer and W. Sarnecki, Ger. Patent 1,059,900 (1959) [C. A., 55, 14511a (1961)]; H. Pommer, Angew. Chem., 72, 811 (1960).

4) K. Suga, S. Watanabe and Y. Yamaguchi, J. Syn. Org. Chem., Japan, 29, 810 (1971). 